
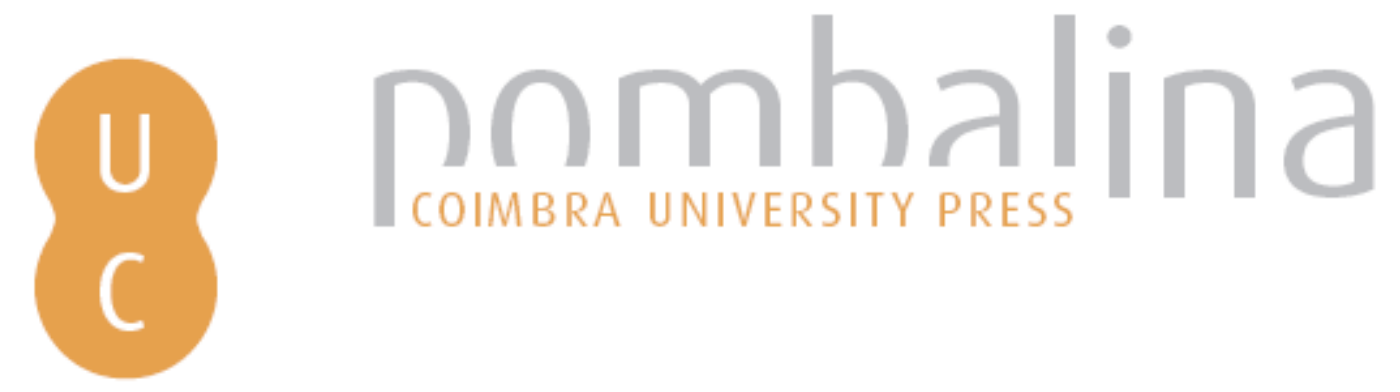

\title{
Influence of moisture and inorganic contents on smouldering spread rates in the lateral and in-depth directions
}

\author{
Autor(es): $\quad$ Christensen, Eirik G; Fernandez-Anez, Nieves; Rein1, Guillermo \\ Publicado por: Imprensa da Universidade de Coimbra \\ URL \\ persistente: URI:http://hdl.handle.net/10316.2/44676 \\ DOI: $\quad$ DOI:https://doi.org/10.14195/978-989-26-16-506_159 \\ Accessed : $\quad$ 26-Apr-2023 11:22:32
}

A navegação consulta e descarregamento dos títulos inseridos nas Bibliotecas Digitais UC Digitalis, UC Pombalina e UC Impactum, pressupõem a aceitação plena e sem reservas dos Termos e Condições de Uso destas Bibliotecas Digitais, disponíveis em https://digitalis.uc.pt/pt-pt/termos.

Conforme exposto nos referidos Termos e Condições de Uso, o descarregamento de títulos de acesso restrito requer uma licença válida de autorização devendo o utilizador aceder ao(s) documento(s) a partir de um endereço de IP da instituição detentora da supramencionada licença.

Ao utilizador é apenas permitido o descarregamento para uso pessoal, pelo que o emprego do(s) título(s) descarregado(s) para outro fim, designadamente comercial, carece de autorização do respetivo autor ou editor da obra.

Na medida em que todas as obras da UC Digitalis se encontram protegidas pelo Código do Direito de Autor e Direitos Conexos e demais legislação aplicável, toda a cópia, parcial ou total, deste documento, nos casos em que é legalmente admitida, deverá conter ou fazer-se acompanhar por este aviso.

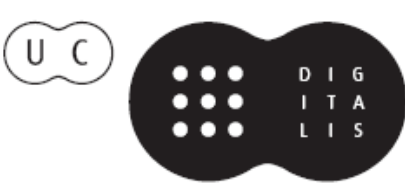




\section{ADVANCES IN}

\section{FOREST FIRE RESEARCH}

\section{8}

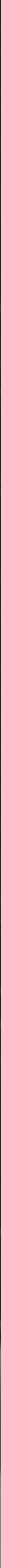


Short contribution - Fire Management

Influence of moisture and inorganic contents on smouldering spread rates in the lateral and indepth directions

\author{
Eirik G Christensen ${ }^{1 *}$; Nieves Fernandez-Anez ${ }^{2}$; Guillermo Rein ${ }^{1}$ \\ ${ }^{I}$ Imperial College London SW7 2AZ, \{e.christensen16@imperial.ac.uk*, g.rein@imperial.ac.uk\} \\ ${ }^{2}$ Western Norway University of Applied Sciences, 5523, Haugesund \{Nieves.Fernandez@hvl.no\}
}

\begin{abstract}
Peat, an organic soil resulting from the accumulation of dead organic matter, is a material that can sustain smouldering fires. Annually, peat fires contribute significantly to wildfire emissions, releasing large quantities of stored organic carbon contributing to positive climate feedback and can be blow into nearby cities causing significant adverse health effects (Hinwood \& Rodriguez 2005). This paper, for the first time systematically studies the influence of moisture and inorganic content, two key soil properties, on the horizontal and indepth spread rate simultaneously. A negative linear relationship was found between spread rate and increasing moisture and inorganic contents. While moisture content apeared to increase the indepth spread rate, decreaseing the inorganic content reduces the spread rate, both tendencies are consistent with the results found in literature. These finding greatly improves the understanding of the influence of soil properties on smouldering spread in thin layers.
\end{abstract}

Keywords: Smouldering, Spread rate, Peat

\title{
1. Introduction:
}

Peatland fires have the ability to emit significant quantities of greenhouse gases (Turetsky et al. 2011; Page et al. 2002) due to the vast quantities of carbon stored in the soil (Huang et al. 2009). Peat predominately burns by smouldering, which is the slow, low temperature form of combustion that occurs in porous char forming media (Rein 2016). It propagates though organic soils in well establish stages: drying, preheating, pyrolysis and oxidation. Drying involves the removal of moisture due to heating, while preheating is the steady increase of the soil temperature, until the onset of pyrolysis whereby temperature are significantly high that the organic material begins to decompose, forming a solid char (Rein 2016). Finally, this char oxidizes - an exothermic reaction that drives the previously mentioned steps.

Smouldering is governed by two fundamental mechanisms: heat transfer and oxygen supply. These mechanisms are affected by a broad range of parameters, being the three most influential, for smouldering organic soils: moisture content, inorganic content and bulk density (Rein 2013). A negative linear relation was found for the critical combinations of moisture content and inorganic content that sucessfully supports self-sustained smouldering (Frandsen 1987). Similarly, both density and moisture content influence the horizontal spread rate of smouldering peat (Prat-Guitart et al. 2016). Notably, the influence of moisture content on the spread rate are different depending if the mode of spread is horizontal or in-depth (Huang \& Rein 2016).

The focus of this paper is to experimentally study the spread of a radial smouldering front examining both the horizontal and indepth spread rate of smouldering propagation as influenced by the fuel properties, moisture and inorganic content. 


\section{Method}

The experiments are conducted using an open top insulated reactor with internal dimensions of 400 x 400 x $15 \mathrm{~mm}$ and a small coil, providing $5 \mathrm{~W}$ for $30 \mathrm{~min}$, placed in the center to ignite smouldering in a bed of commercial peat, creating a radially propagating smouldering front. The spread is monitored using a visual and infrared camera.

Time lapse images, spaced by $60 \mathrm{~s}$, are taken from directly above the ignition and the image series are analyzed in Matlab. The center of the image is manually selected based on the location of the coil and the scale is set based on comparing the number of pixel width of the reactor and its known length. A conservative estimate of the scale error is calculated to be $2 \%$, based on repeated measurements of the pixel number. The time lapse infrared images are grayscaled and intensity profiles of 60 evenly spaced transects originating from the center of the ignition and extending outwards is retrieved. The location of the first and last value to cross a threshold value signifies the trailing and leading edge. Comparing the change in position of these edges in subsequent images and dividing by the time between images give the spread rate. The in-depth spread rate at a given position can be evaluated by dividing the depth of the sample by the time taken between the leading and trailing edge to pass the said horizontal position. This concept is presented in Figure 1, as the first instance of smouldering occurs once the char forms, after which the peat is consumed in depth; Then finally, the trailing edge marks the complete consumption of the fuel.

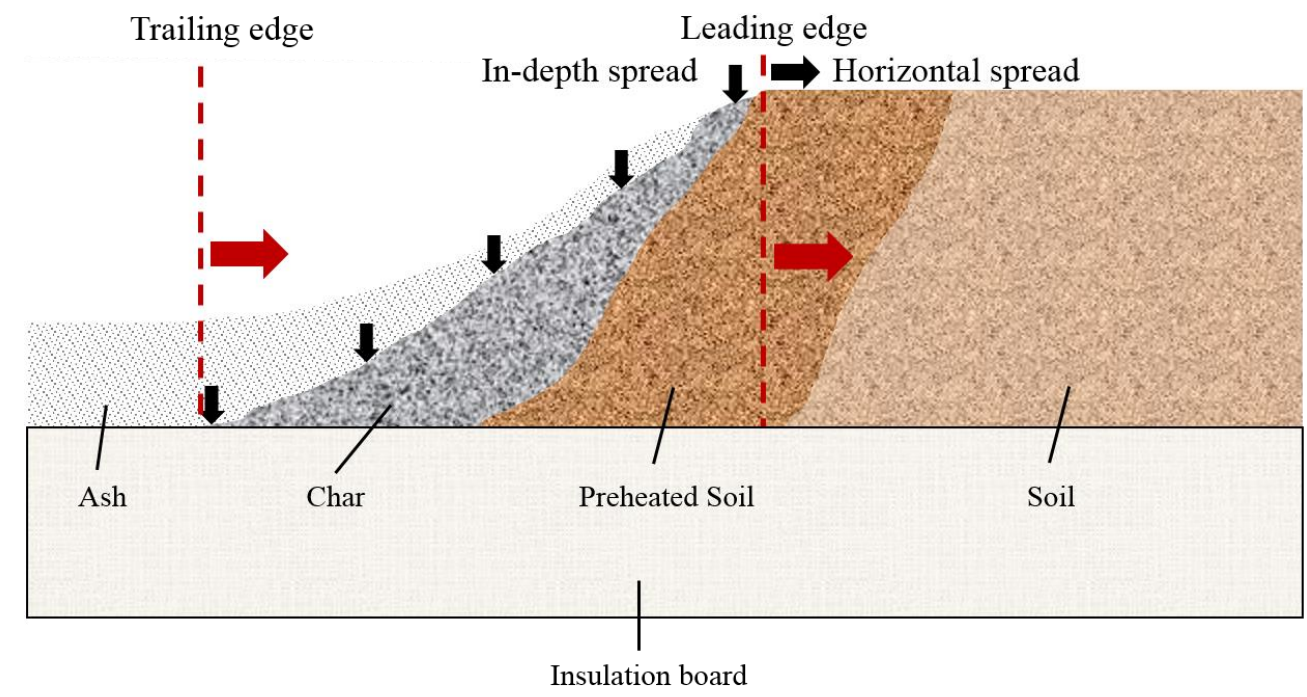

Figure 1 - Profile view of smouldering. Illustrating the how the leading edge is a function of the horizontal spread rate, while the trailing edge is determined by the horizontal spread rate and the depth of the sample.

\section{Results \& discussion:}

For the first time, this study shows the diminishing horizontal spread rate with increasing moisture content across a range of inorganic contents as well as shown a negative linear relationship between horizontal spread rate and inorganic content owed to the increasing heatlosses. Both moisture and inorganic contents have a similar influence on horizontal spread rate, but they have a diverging effect on indepth spread rate; whereby an increase in moisture content was found to increase the in-depth spread rate while inorganic content was shown to decrease the speed of spread. This finding is supported by previous researches. The influence of soil properties were also visually observable. Figure 2, is a composed image and illustrates key differences resulting from varying fuel properties. The image on the left is a sample with minimal inorganic content (2.5\% dry basis) and a moisture content close to the critical value $(110 \%)$, while the one on the right has a inorganic content near the 
critical value $(70 \%)$ with minimal moisture content $(0 \%)$. It is clear that the peak temperatures, surface coloration, thickness of smouldering wave, and spread rates of both the front and trailing edge are influenced by the fuel properties.

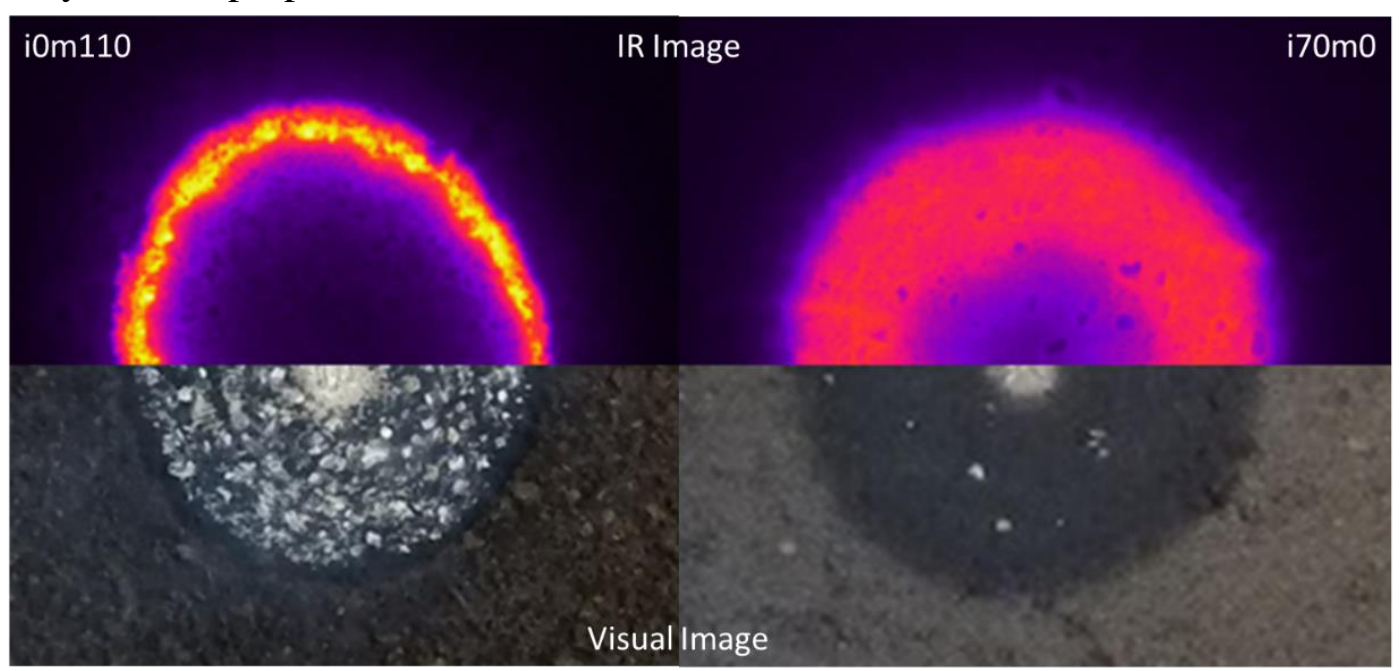

Figure 2 - Comparing infrared and visual images of smouldering samples with different fuel properties. The composite image on the left is a sample with almost zero inorganic content and $110 \%$ moisture; the image of the right has $\mathbf{7 0 \%}$ inorganic content and near zero moisture content. The smouldering front is seem to be more narrow and hotter how the high moisture condition and produces more ash at the surface.

\section{Conclusion:}

The systematic study of the influence of soil properties on the smouldering spread both indepth and horizontal provide understanding for the smouldering dynamics and can inform land managers and firefighters as to the risks of smouldering fires.

\section{References}

Frandsen, W.H., 1987. The influence of moisture and mineral soil on the combustion limits of smoldering forest duff. Canadian Journal of Forest Research, 17(12), pp.1540-1544.

Hinwood, A.L. \& Rodriguez, C.M., 2005. Potential health impacts associated with peat smoke: A review. Journal of the Royal Society of Western Australia, 88(3), pp.133-138.

Huang, P.-T. et al., 2009. Classification of Organic Soils. Soil Science Society of America Journal, B7(1), p.108.

Huang, X. \& Rein, G., 2016. Downward Spread of Smoldering Peat Fire: the Role of Moisture, Density and Oxygen Supply. International Journal of Wildland Fire [under review], (Mc).

Huang, X., Rein, G. \& Chen, H., 2015. Computational smoldering combustion: Predicting the roles of moisture and inert contents in peat wildfires. Proceedings of the Combustion Institute, 35(3), pp.2673-2681. Available at: http://dx.doi.org/10.1016/j.proci.2014.05.048.

Page, S.E. et al., 2002. The amount of carbon released from peat and forest fires in Indonesia during 1997. Nature, 420(6911), pp.61-65. Available at: http://www.nature.com/doifinder/10.1038/nature01141.

Prat-Guitart, N. et al., 2016. Propagation probability and spread rates of self-sustained smouldering fires under controlled moisture content and bulk density conditions. International Journal of Wildland Fire, 25(4), pp.456-465. 
Rein, G., 2016. SFPE handbook of fire protection engineering, fifth edition. SFPE Handbook of Fire Protection Engineering, Fifth Edition, pp.1-3493.

Rein, G., 2013. Smouldering Fires and Natural Fuels. Fire Phenomena and the Earth System: An Interdisciplinary Guide to Fire Science, (1984), pp.15-33.

Turetsky, M.R. et al., 2011. Recent acceleration of biomass burning and carbon losses in Alaskan forests and peatlands. Nature Geoscience, 4(1), pp.27-31. Available at: http://dx.doi.org/10.1038/ngeo1027. 